\title{
IMPACT OF ICT TOOLS AND APPS ON TOURISM DESTINATION MARKETING. A CASE OF RDB AND MARRIOT HOTELS, KIGALI, RWANDA
}

\author{
Emily Atinda Masaki ${ }^{1}$, Mr. Wanyera Francis John² and Mr. Condo Abel ${ }^{3}$ \\ ${ }^{1}$ Department of leadership at African Leadership University \\ ${ }^{2,3}$ Department of Travel and Tourism management at University of Tourism, Technology and Business \\ Studies
}

DOI: 10.46609/IJSSER.2021.v06i04.008 URL: https://doi.org/10.46609/IJSSER.2021.v06i04.008

\section{Introduction}

The tourism industry is diverse with interconnections of both private and public service and product providers to attract visitors at their sites. As a result of these interconnections, sometimes the accessible facilities end up conflicting in the way they create experience to the tourists. Meanwhile both visitors with and without disabilities create demands for accessibility to the tourism sites (Stumbo and Pegg, 2005). Even if the prerequisites, abilities, needs, wants, interests and preferences differ. There are hidden disabilities that may not be exposed such as allergies, asthma or diabetes which in one way or another have different impacts on the traveler. However, the common dimension that majority demand for is the necessary requirements that give them chance to fully participate in the tourism activity and enjoy full experience (Buhalis, 2003). To minimize the accessible limitations the destination sites need to ensure physical accessibility of the site and tourism services, effective delivery of information linked to accessibility. In this regard, access to information is foundation whereas the physical accessibility is a prerequisite to access, to products, services, information and facilities (Israel, 2003).

UNWTO (2013) defines accessible tourism or tourism for all as making travel possible to tourism destinations, access hotel and tourism products, and required information for all those that have particular accessibility needs. These include mobility, vision, hearing and other cognitive dimensions of access as well as parents traveling with their children. The concept of accessible is not a recent one but it has been brought to the forefront by the tour operators, tourism businesses and destination sites in past decade after noticing that there is an increase in demand for accessibility.

Other researchers defined accessible tourism as accessible tourism that enables people with access requirements including mobility, vision, hearing and cognitive dimensions of access to function independently and with equity and dignity through the delivery of universally designed 


\section{International Journal of Social Science and Economic Research}

ISSN: $2455-8834$

Volume:06, Issue:04 "April 2021"

products, services and environments at a tourism site (Darcy and Dickson, 2009). They add that this definition encompasses all people including those traveling with children in prams, people with disabilities and seniors. Having said that it therefore implies that accessible tourism targets any segment of the market that prefers accessing a tourism a experience with ease, which can be through continuous pathways, tactile surfaces, clear and bright signage especially for the disabled tourists and seniors(law et al, 2010).

Tourism destinations to be competitive and successful depends on the perception and awareness of the tourists, customer acquisition, satisfaction and retention. Tourism and travel experiences for people with disabilities still remain highly restricted by physical barriers that include transportation constraints, inaccessible accommodation and tourism sites (Darcy and Dickson, 2009). In addition to inaccessible information due to poor inadequate and not well designed website links, the challenge of inadequate information plays a role. Not only that, most of the tourism destinations have ignored and failed to offer information about how accessible their sites are and even not develop all inclusive principles. Also lack of knowledge and negative attitude towards disabled people, generates no actual needs, in addition to social segregation and stereotype bottlenecks for offering and caring for their accessibility (Yau, et al 2004 \& Small et al, 2012).

Similarly lack of reliable information, is considered as a hindrance factor that stops individuals not only with disabilities but all interested persons to visit a tourism destination. Accessibility of information for any tourism destination sites is crucial since it enables the tourists to effectively make informed decisions (Morrison et al, 2001). Also information on facilities accessibility requires reliable up to date information. The destination information has to be detailed and inclusive in that it must consider all markets. The point is that richness of information influences destination site selection and so display of reliable accessible information on the inter-linkages of the individual accessible facilities, products, services as well as interpretations gives a full package for the visitor to switch destination sites (Slatin and Rush, 2003).

Conversely, many destination sites especially the historical and highly sensitive environmental sites have not yet prepared and equipped well for accessible tourism particularly tourism sites in developing countries. However, this has started changing slowly due to competition and changes in customer preferences (Bizjak, etal 2011). Implementing accessibility at natural tourism sites, hotels, restaurants and cultural sites depends on the business owner but majorly is a collective effort of all stake holders. For instance travelers with disabilities will definitely choose a destination site that has got most of the accessible options in terms of hotels, restaurants, public transport and tourist attractions and accessible accommodation a key foundation for any visit (Kleinman, 2012) 


\section{International Journal of Social Science and Economic Research}

ISSN: $2455-8834$

Volume:06, Issue:04 "April 2021"

In the same line (Small et al 2012), argued that globally there are over one billion people with disabilities plus more than two billion persons, such as spouses, children and caregivers of persons with disabilities, that represent about one third of the world's population who are directly affected by disability. This signifies that there is a big potential market for travel and tourism that still remains untapped due to inaccessible facilities and services at the tourism sites.

Buhalis, et al 2005; Darcy and Dickson 2009 all share the same arguments that accessible tourism involves a collaboration of all stake holders such as governments, hotels, international agencies, tour operators and end users, including people with disabilities and destination management systems. The argument is that a successful tourism product requires effective partnerships and co-operations across different sectors at the national, regional and international levels. For any destination site to be accessible, many intertwined factors are involved. These may include but not limited to the following; accessing information, long- distance travel complexes, local transportation, accommodation, shopping and dining. It therefore implies that the impact of accessible tourism goes beyond the tourist beneficiaries to the wider society, strongly rooting accessibility deep in socio-economic aspects of the people involved.

\subsection{ICT tools and Apps as a marketing strategy}

ICT refers to Information Communications Technology (Unwin, 2009) and in connection to previous discussion, applying Information Communications Technology (ICT) facilitates potential travelers to be able to access richer reliable information about particular target destinations of interest. in that respect, ICT acts as an open door for the new, widely experienced, highly sophisticated and inquisitive traveler to access the suppliers products and services to satisfy his/her insatiable needs and experiences (Morrison et al., 2001). In a similar situation, the availability of the ICT increases accessibility to a particular destination in that bookings are done in a blink of an eye and cuts out the hustle of calls which makes it more reliable and time saving (Zins, 2007). Additionally, ICT has been found to be offering unique accessible tools that simplify and increase tourism accessibility at tourism sites to consumption of products and services. The facilitation has been through applications that enable easy access and consumption by tourists information related to travel and be able to process and book online tickets. This improves also tourism accessibility due to the fact that they do hotel room bookings via internet, tourism activities at destination sites can be booked online and other related services the tourists would wish to enjoy at a tourism site (Mills and Law, 2004; O’Conner, 1999).

Additionally, a number of tourism product and service suppliers have used ICT as a strategy to out compete other similar suppliers and make it more accessible for tourists to enjoy what they offer at a tourism site. In this industry the key suppliers include; attraction sites, lodging facilities, tour operators, travel agencies and government entities, as well as information centers. 


\section{International Journal of Social Science and Economic Research}

ISSN: $2455-8834$

Volume:06, Issue:04 "April 2021"

As a result of the ICT tools, tourist consumer behavior has kept shifting due to being part of the functionality of the product development process especially special needs tourists (Morrison, et al, 2001). Other studies by (Mills and Law, 2004; O’Conner, 1999 and Kotler 1999), have indicated that tourism accessibility and internet are linked especially in product consumption and customer experience. They added that all consumers get involved in a five step decision making process before they finally purchase a product or a services at a destination. These steps include the first one is to recognize a need, secondly find out the reliable necessary information, thirdly weigh options and find the most beneficial and satisfying, fourth is the effective buying or purchase and five the after purchase behavior which will determine loyalty (Puhretmair, 2004).

Tourism accessibility through ICT has been influenced through the fast technology developments that led to more efficient and affordable as well as end user friendly which motivates more travelers to access the products and services at the destination sites(Darcy and Dickson, 2009). The continuous improvements and innovations of ICT tools as well as network modifications has given chance to tourists to recognize its linkage to accessible to tourism at attraction sites. In the same way it has given a competitive edge to tourism sites that have made ICT more effective and efficient as well as user friendly to the travelers in all groups such as elders, families, disabled ones and able ones in influencing accessible tourism (Buahils, 2003). O'Conner and Frew, (2001) highlighted that internet and its applications have enabled accessibility to tourism sites and thus accessible tourism. The tourism companies have developed information structures that enables transfer of information within their companies as well as out to its prospective customers for fast data acquisition, process and dissemination to the interested potential travelers. The studies about ICT applicability and easy access to travelers indicate that innovated web technologies promote tourism accessibility via tourism information systems that are richer in relevant and updated information. The information centers and websites have modified the generation of sematic descriptions that can be easily accessible and interpretable by the programed machines for the tourists that may have access to them (Maedche and Staab, 2003).

Similarly Jakkilinki et al, (2007) argues that use of ontology based e-tourism planner-AuSTO which has the capacity to create an itinerary automatically. Further, ultimate experience created by innovated computer-mediated environments have the capacity to create a real visit and virtual experience and offer an almost real-life experience. ICT influences accessible tourism in a way that use of the new technology plays arole in motivating travelers. For instance the use of multimedia is becoming popular in a way of influencing travelers through well graphically represented photos of tourism sites to create a tangible image to potential travelers creates accessibility to the targeted attraction site(Agrawal, et al 2003). That aside, use of ICT leading to accessible tourism in the adoption of 3D photos through interactive web sites by the tourism 


\section{International Journal of Social Science and Economic Research}

ISSN: $2455-8834$

Volume:06, Issue:04 "April 2021"

companies to market their products online stimulates online buyers to buy and increase retention, sales and thus loyalty of travelers because sites become accessible (Fiore et al, 2005). Tele-presence has been another new innovation in ICT use to ease accessibility to sites as the travelers enjoy those attractions. In fact tele-presence allows the interested person to enjoy and experience products and tourism sites without physically visiting that particular site (Steuer, 1992).

Another way the ICT has promoted accessible tourism is through web-site design and analysis. Most tourism product and service providers have developed and designed web-sites that have got content, user friendly able to navigate and promote interactions with the tourists or hotel guests (law et al, 2010). In the same line the authors argued that a web-site can only be successful if it can take interests of customers, interaction and participation so that it can capture relevant information about their preferences and their after utilize the information to customize the communication and services or products he needs. These applications create a quick and accessible interface between the prospective traveler and the supplier and in doing this it will have contributed to accessible tourism at that particular tourism site (Dolin, et al, 2002; Hashim et al 2007). Additionally, a website is said to be universal when it is inclusive and generally caters for the needs of different types of online users, consisting of visually impaired and disabled users as well (Shi, 2006; Han, and Mills, 2007). For accessible tourism to be also inclusive, then hotels and tourism providers have to put in consideration people with disabilities, families as well as the seniors because it the recent growing market. In terms of accessible tourism, the providers have to ensure to include assistive ICT tools such as Voice browsers that may offer help to this category of travelers to have access to web-site information that may motivate them to visit areas offering accessible tourism services and products (Puhretmair, 2004).

ICT role in influencing accessible tourism has been applicable in online marketing to attract the prospective travelers to purchase the tourism products and services from the tourism sites. As a result of increased awareness of the tourists, about the tourism products, it has led to increased online distribution, and purchase. This has led to tourism suppliers investing a lot in advanced technology in order to improve management, sales and out compete the competitors by ensuring that easy accessibility of such products (O;Conner and Frew, 2002). In the similar way, efficient online marketing that effectively and efficiently reaches out to potential tourists at a low cost gives the company an opportunity to interact with many customers at once which really enables the tourism site to be easily assessed. In addition, the ability of the web to be accessible in terms of information, will also be effective in the situation where it has performs the duty of coordination of various website tools, have promotional properties as well as perform customer 


\section{International Journal of Social Science and Economic Research}

ISSN: $2455-8834$

Volume:06, Issue:04 "April 2021"

relation management activities to enable the customer enjoy the inclusive services offered (Buhalis, 2003).

However, online marketing has its weaknesses which are linked to user friendliness on part of the tourist especially the disabled ones. This creates a gap of accessibility of the prospective tourists to pick interest to visit a tourism of interest and hence affecting accessible tourism promotion. Similarly, to some of them surfing has been observed to be a barrier for instance those with visual disabilities. These prospective travelers may have problem with low vision and so need large size text also blind persons who will require screen readers, color blindness that need adequate contrast of text and background colors. While the deaf disabled individuals need visual displays rather than pure audio presentations (Michopolous et al, 2007). Further, due to the non-standardized data formats among the various available systems, there are difficulties with interoperability (McGrath and Abrahams, 2006; Cardoso and Lange, 2007). In addition, another challenge for adoption of such package assemblies is the language barriers. These barriers result in the mobile information provided not being the latest available because of delays in transmission (Chen and Hsu, 2000). These factors make it difficult for ICT to influence promotion of the tourism sites due to the fact that they are not accessible and thus hindering accessible tourism in particular tourism sites. The specific objectives of the study were; to determine different ICT tools used by RDB and Marriot Hotel to market their products and servicesto enable customers have access to them; to determine methods used to promote accessible tourism; and to ascertain the challenges hindering use of the ICT tools and accessible tourism and the way forward.

\section{Methodology}

The study was carried out in Kigali hub which comprised of the capital city of Rwanda, geographically located at the heart of the country. It covers an area of approximately $730 \mathrm{~km}^{2}$. In addition, the city is made up of three districts namely Gasabo, Kicukiro and Nyarugenge. The population in Kigali city is approximately 1.25 million people comprising of majorly the youth making about $60 \%$ and women slightly above $50 \%$. Kigali hub has of recent grown rapidly and has changed into a modern city and also an important business center particularly for tourism and hotel businesses. Numerous local and international hotels have of recent entered the market as well as growth of tourism in form of MICE tourism. So the research design of the study was descriptive and used both qualitative and quantitative approaches as well as considered primary and secondary data. Marriot Hotels Kigali and Rwanda Development Board (RDB) were the two main organizations considered in this study. This was mainly because RDB acts as the tourism marketing arm of the government of Rwanda while Marriott Hotel was selected on basis of a five star international hotel majorly sought by tourists. The population of study was 150 staff of both RDB, Marriott Hotel Kigali branch and visitors (guests and tourists). The sample size was 


\section{International Journal of Social Science and Economic Research}

ISSN: $2455-8834$

Volume:06, Issue:04 "April 2021"

obtained by Slovene's formula which was 60 respondents taking the error of margin to $10 \%$ or 0.1.The sampling techniques were convenience sampling for the staff of the organizations selected and visitors. Due to restrictions during COVID 19, the study used mainly emails to send questionnaires to the targeted respondents especially the staff of both organizations who could not be accessed physically. Interviews were carried out at RDB reception area for tourists. The study used Linkert's 10 point scale to quantify the respondents' opinions. Data collection was carried out by questionnaires, interviews and data was presented in form of Tables, and essay form and analysis utilized frequencies, percentages and means by computer package Excel.

\section{Results and discussion}

Results in Table 1, from key informants indicated that Marriot Hotel Kigali had installed some of the best ICT tools in form of apps that facilitated the guests to access its products and services. The respondents added that the hotel had set standards to ensure quality service and easy accessibility to its products and services. Marriot Mobile App was ranked highest ( 9 or $90 \%$ ) as one of the best user friendly tool that all guests of all ages can use to access the hotel services. This App informs the guest and updated him or her on services offered while giving options. It also enabled the guest to check in before he/she arrived in the hotel as well as gave notifications on room readiness and thus increased room experience. The App further, played a crucial role in service, where it enabled the guest to be accessed anywhere at any-time in the hotel premises to deliver his order or service required. The tool also gave chance to the guest to request his/ her orders access hotel facilities at all times but also chat with hotel staff before arrival. In addition, the hotel has got a website which was ranked (9 or 90\%) that acted as a tool for accessing the hotel, facilities, products and services. The website displayed the photo gallery and unique services that can be accessed by the prospective guests. This ICT tool also helped to market the products, services and other required facilities that potential guests wished to access. The keyless App ranked ( 8 or $80 \%$ ) was another tool used by Marriot Hotel Kigali. The App was used as a key to access the room and it allowed the guest to skip the check in process and go straight to the room. The App was programmed to enable the guest to unlock the door with the help of a phone. This tool created a comfortable and suitable environment and experience for the disabled, fatigued and senior guests to have access to hotel room services without difficult. In addition, there was the Red coat request App which also ranked (8 or 80\%) had similar applications to the previous Apps but unique in that it enabled accessibility of facilities, services and products much more-easier by all guest of different age groups, disabled or not disabled. The App is used by guests in the dinning or seated at any location in the hotel and need more service or to access any other service in another facility. The guest pressed the button at table and the request in forwarded to the correct point to deliver the required service. The Meeting service App ranked ( 8 or $80 \%$ ) was initiated to improve the service during meetings and conferences. The App allowed 


\section{International Journal of Social Science and Economic Research}

the guests or managers to handle details of an event in just a single tap. The App allowed smooth flow of meetings without stress while ensuring. This App enabled the participants in the meeting from different back grounds with different languages to have no difficulties because it enabled solved such hindrances. It also enabled the planners and hotel event managers to get connected to any web enabled devices in real time to facilitate events smoothly. The key informants said that Marriot hotel Kigali also used ICT tools called Marriot Rest-Link ranked also at (8 or $80 \%$ ) direct that enabled easy reservations for rooms in the group block without entering separate discount codes. This App has the capacity to enable a group of guests that had an event to send emails or information to all those supposed to attend and even posit the required information on the event website. For ICT tools and accessibility to hotel services, the key informant added that Meeting App which was ranked (7 or $70 \%$ ) majorly used to enhance meeting proceedings by enabling upgraded fast Wi-Fi and giant screens particularly that facilitated those with visual difficulties and ensured guests are continuously connected to ongoing meeting in the room. This also enabled those who were in hotel facilities but wished to follow the discussion in the meeting. Lastly the respondents pointed out that among the key ICT tools used in the Marriot Hotel Kigali was the meeting imagined App, Twitter, and Face-book ranked (6 or 60\%). The social media commonly used were Twitter and Face-book to market and inform the prospective guests about the current and future services. Meeting imagined app enabled the guests and planners of an event to get a lot of ideas to enrich the in-coming event or improve the scheduled event to offer the quality services to the event attendees. The App gave innovative ideas about food and beverage styles, accompaniments, garnishes, cold and hot foods, photo gallery as well as professional tips that gave an equaled experience to the guests plus guiding the planners through a planning process needed. These findings were in line with studies of researchers such as Frew, 2001 and Zins, 2007 who agreed that ICT tools such as internet allow easy accessibility of tourists to tourist attractions. The previous discussion on apps were indicated in Table 1.

Table 1: Rankings ICT tools used in Marriot Hotel Kigali to market \&access the products and services

\begin{tabular}{|l|l|}
\hline ICT tools Applications & Linkert's (1-10 point scale) Ranking \\
\hline Marriot Mobile App & 9 \\
\hline Social media (Twitter \&Face book & 6 \\
\hline Keyless App & 8 \\
\hline website & 9 \\
\hline Red Coat request App & 8 \\
\hline Meeting Technology & 7 \\
\hline
\end{tabular}


International Journal of Social Science and Economic Research

ISSN: 2455-8834

Volume:06, Issue:04 "April 2021"

\begin{tabular}{|l|l|}
\hline Meeting Service App & 8 \\
\hline Meeting Imagined App & 6 \\
\hline Marriot Rest-Link App & 8 \\
\hline
\end{tabular}

Source: primary data, May 2020

Table 2, findings indicated that, key information informants (KII) agreed that, Marriot Hotel Kigali put in place ways that were used by guests to achieve accessible tourism and accessibility to their products and services. The informants ranked the open restaurant self-service design highest (9) as one method used to allow the guests of all ages, disabled and non-disabled to access the services and products. The design gave chance to guests to select what they desired and this increased the experience of guests and satisfaction. Another method was the use of technology which was ranked ( 9 or $90 \%$ ) by the respondents. The respondents indicated that the use of technology such as mobile telephone, IPad, micros to make orders gave chance to all guests regardless of the status, disabled or not disabled to access the services and products as quick as possible. Apart from that, the respondents agreed that Interactive Map app ranked (9 or 90\%) was key in promoting accessibility to products and services. This App is user friendly and gave the guest the opportunity to scan around the map of the destination and highlight the points of interest to the guest so that in case he made a decision to visit that particular site, he will have got in touch with sit guides. Additionally, the key information informant (KII) mentioned that open kitchen and ethnic cuisines were ranked (8) catered for all guests that visit the hotel. He highlighted that open kitchen allows involving the guest in cooking and this created that feel that he cooked and enjoyed the finished product served to him. The ethnic cuisine also made guests enjoy the home dishes and as such feel special and at home when served the home delicacy which embraces everyone and thus created that belong and satisfied.The respondents argued that Marriot Hotel Kigali offered quality room and housekeeping service for example family rooms and provide extra beddings at no cost ranked at (8 or $80 \%$ ). In order to encourage even people with families to visit the hotel and show inclusiveness in the services and facilities offered. This was one way the hotel was encouraging accessibility to its services. Another method was encouraging the guests to access the hotel accommodation facilities. Through use of phone to self-check in and self-check-out where ever the guest happened to be and also use of a tool known as Trip planner which was ranked (8 or 80\%). This Apps enables the guest to have options about hotel facilities, tourism activities and made it easy for the guest to make decisions basing on the preference of the guest. Further, the hotel also ensured that there was easy physical accessibility to hotel facilities such as washrooms for disabled, wheel chairs were put in place as well as the lifts to be used by the seniors and disabled in case they were booked on floors beyond the first level and were ranked (6 or $60 \%$ ). The respondents agreed that this provision made these 
categories feel special and valued and so enjoyed accessing the facilities and services in the hotel. Finally the key informants mentioned that the ground floors were majorly reserved for the disabled guests ranked (6 or $60 \%$ ). The hotel has it as a policy that guests with problems to move were advised to stay on ground floor to enable them have easy movement and access to restaurants, open kitchen and bar without difficulty. In support to the above, the authors that included Bizjak, et al 2011; Kleinman, 2012; Darcy and Dickson, 2009 highlighted that hotels needed ICT tools to enable the travelers and guests to access their services and products. The results in Table 2 below summarizes the previous discussion.

Table 2: Ranked Key Methods used to promote accessible tourism by Marriot Hotel Kigali

\begin{tabular}{|l|l|}
\hline Methods & Linkert's (1-10 point scale) Ranking \\
\hline $\begin{array}{l}\text { Easy physical access to hotel facilities for all } \\
\text { clients }\end{array}$ & 6 \\
\hline Dinning and restaurant order accessibility & 7 \\
\hline Open Restaurant self-service design & 9 \\
\hline Open kitchen design \&Ethnic Cuisines & 8 \\
\hline Use of mobile App technology & 9 \\
\hline Health related meals & 7 \\
\hline Self-check in and check-out service & 8 \\
\hline Room and housekeeping service & 8 \\
\hline Interactive Map App & 9 \\
\hline
\end{tabular}

Results in Table 3 indicated that the majority of the respondents (27\%) agreed that RDB majorly used websites for example IREMBO. The respondents argued that the most common ICT tool used by RDB was the websites to access the tourism products and services offered in Kigali hub. Apart from that, some of the respondents that were $20 \%$ highlighted that RDB used the social network Apps such as face-book, twitter, to enable the tourists to access their products and services in Kigali hub. In addition, 16\% of the respondents agreed that RDB used electronic media to allow the tourists access the Kigali hub tourism products and services. Smart trip planner was another ICT tool used as mentioned by $12 \%$ of the respondents and it was used to allow the tourists to have access to the Kigali hub tourism products and services. Also trip advisor was another ICT tool used as agreed by $13 \%$ of the respondents, who highlighted that through usage of the tool they were able to access the tourism products in Kigali hub. Finally the smallest percentage pointed out that Google map App was one of those ICT tools which was 
used to access the tourism products and services in Kigali hub. The results under this section were in agreement with the study findings of researchers such as (Shi, 2006; Han, and Mills, 2007; Mills and Law, 2004; O'Conner, 1999 and Kotler 1999; Puhretmair, 2004; and law et al, 2010). These authors agreed that for tourism sites to enable their consumers to have access to their products and services, the suppliers must put in place the necessary ICT tools and Apps to create easy access to the hotel and tourism products and services.

Table 3: Key ICT tools used by RDB to market \& promote accessible tourism in Kigali City

\begin{tabular}{|l|l|l|}
\hline Responses & Frequencies & \\
\hline Electronic media & 10 & 16 \\
\hline Websites (Irembo) & 16 & 27 \\
\hline $\begin{array}{l}\text { Social Networking Appse.g Facebook, } \\
\text { Twitter }\end{array}$ & 12 & 20 \\
\hline Photo Library App & 5 & 8 \\
\hline Smart Trip Planner & 7 & 12 \\
\hline Google Map App & 2 & 6 \\
\hline Trip Advisor & 8 & 13 \\
\hline Total & 60 & 100 \\
\hline
\end{tabular}

In relation to the results above the study investigated key factors that hindered the smooth usage of ICT tools to access the tourism products and services. Table 4 revealed that, majority of the respondents

(27\% ) agreed that change in market trends in terms of health related issues and lifestyles of the travelers influenced a lot which tool they used to access the tourism products and hotel services in the Kigali hub. Additionally, the second highest number of respondents (25\%) agreed that one of the factors that had hindered the accessibility of the tourism products and services was the high cost of maintaining the ICT infrastructure that enabled the travelers to access and consume the products and services offered. The study findings revealed that the a reasonable number of respondents (20\%) emphasized that as a result of COVID 19, many of the tourism products and hotel services were not accessible due to the travel health measures and restricted movements. More to that, the results indicated by some respondents $(16 \%)$ that some of the suitable travel Apps and ICT tools were expensive and so they were not easily acquired by RDB and Marriott easily which played a role in how also easily the travelers could have access to the products and 


\section{International Journal of Social Science and Economic Research}

ISSN: $2455-8834$

Volume:06, Issue:04 "April 2021"

services in the Kigali hub. Finally, the findings showed that the minority of the respondents who were $(12 \%)$ agreed that lack of necessary resources for example disposable income and gadgets needed to be used played a big role in denying accessibility and consumption of the tourism products and hotel services in Kigali hub. In the same vein the studies done by (Darcy and Dickson, 2009; Slatin and Rush, 2003) argued that travelers to tourism sites and hotels may fail to access the products and services due to lack of easy access, internet and information gap that hinders the tourists and guests to hotels to visit such tourist destinations. The studies carried out by (Buahils, 2003). O'Conner and Frew, (2001); Fiore et al, (2005)and Jakkilinki et al, (2007) indicated that use of ICT tools and Apps promoted the accessibility and consumption of the tourism products and hotel services.

Table 4: Factors that hindered usage of ICT tools and accessible tourism to market Kigali City hub

\begin{tabular}{|l|l|l|}
\hline Responses & Frequencies & Percentage \\
\hline Expensive to maintain ICT infrastructure & 15 & 25 \\
\hline Expensive up-to-date APPs & 10 & 16 \\
\hline Lack Necessary resources \&gadgets required & 7 & 12 \\
\hline Market trends and lifestyles & 16 & 27 \\
\hline Pandemics (COVID 19) & 12 & 20 \\
\hline Total & 60 & 100 \\
\hline
\end{tabular}

Source: primary data 2020

The results in Figure 1 indicated that, respondents pointed out the key Apps and software's that the hotels and RDB could use to improve the tourist experience and accessibility to the tourism products and hotel services. According to the respondents, the majority (27\%) argued Nano Hotel Booking and property management software which is the newly developed for hoteliers. It has got a calendar that informs about room occupancy, vacancies current and future room status of room availability in one click. It has capacity to make room reservation management, customer relationship management, loyalty programs. Extended stay, marketing automation, annual calendar, payment dynamics as well as the preferred rooms. The reasonable numbers of respondents ( $22 \%$ ) said that Tourism art was the best App to be used by RDB because it makes it easy to handle reputation or image of a destination, reservations, tourist needs, understand what the users prefer or want as well as income expenditure checks to know how much revenues are received. The results also indicated that the respondents $(11 \%)$ highlighted that cloudbeds was another App that was new and developed for particularly hotels. It was pointed out it was of 
the leading hotel management soft-wares that helped the top technology hotels to optimize their profits and reduction of costs. It plays a crucial role in workflow patterns that produce quality service and increase customer satisfaction. It was mentioned that it can also be used for both front office and back office to facilitate the proper functioning of hotel operations. Additionally, a big number respondents (17\% ) agreed that one of the modern App used by the high class chain hotels was ALICE. The respondents agreed that this App has got a property management system which can be integrated in the internal communication system. The App enables the guests to express their needs, concerns and inquiries. The results indicated that this App simplifies task management, does guest tracking, guest engagement, and also helps to identify what the guest likes most. Finally the respondents ( $23 \%$ ) also agreed that TripIt App helped the tourists to separate and easily identify the itineraries and documents by automatically organizing them. it also helped the tourists to make reservations, flight itineraries, tickets, hotels and Airbnb booking information, rental cars and driving directions.

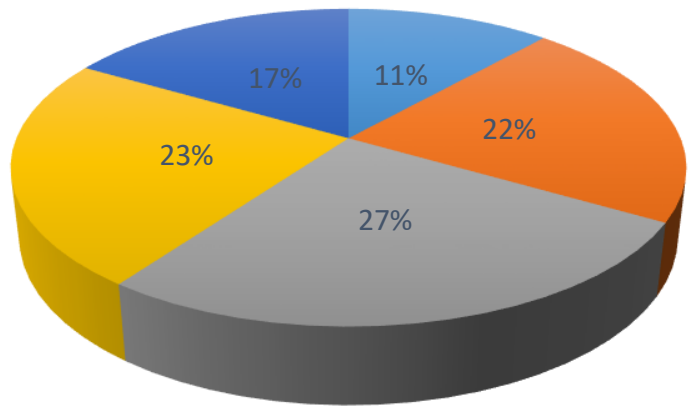

Alice Tourismart Nano hotel booking Triplt cloudbeds

Figure 1: The Apps and softwares that could be used in RDB \&Marriott Hotels Kigali

The results in Table 5 revealed that, as much as there were a number of hindrances highlighted, the respondents suggested possible measures that could be used to over-come the mentioned hindrances. The majority of the respondents $22 \%$ agreed that it was necessary to acquire modern and updated ICT tools and Apps in order to enable the travelers to have access to the tourism and hotel services in Kigali hub. In addition, it was also agreed by $20 \%$ of the respondents that one other measure was the development of ICT infrastructure which was to facilitate accessibility and consumption of the tourism and hotel products and services in Kigali hub. Further, it was emphasized by $17 \%$ of the respondents that to minimize hindrances to the tourism and hotel services, it was necessary to put in place the facilities to enable accessibility and consumption of the tourism products and services. In addition, creation of awareness on both sides of travelers, guests and staff as well as involving all the concerned stake holders in the ICT tools and Apps 
usage was highlighted by $13 \%$ of respondents respectively. Some of the respondents emphasized that it was important for government to partner with the private sector particularly to strengthen the implementation and development of ICT tools and Apps that can be used in tourism and hotel service and product consumption. Finally a small number of respondents which was 5\% percent said that it was also important to diversify the tourism and hotel products and services to give a wider choice so that it could enable the visitors to quickly access a variety of those on sale in Kigali hub. In the studies carried out by researchers such as Jakkilinki et al, 2007; Buhalis, 2003; Dolin, et al, 2002; and Hashim et al 2007 revealed that ICT tools and Apps were the best competitive tools used to enable the travelers and hotel guests have access to the tourism sites and hotel without physically visiting the establishment.

Table 5: Suggested measures to minimize the hindering factors

\begin{tabular}{|l|l|l|}
\hline Responses & Frequencies & Percentage \\
\hline Government to Partner with private sector to raise funds & 6 & 10 \\
\hline Continuous creation of awareness facilities to enable & 10 & 13 \\
\hline $\begin{array}{l}\text { Improvedtourism and hotel } \\
\text { accessibility }\end{array}$ & 3 & 17 \\
\hline Diversify the tourism and hotel products and services & 12 & 5 \\
\hline ICT Infrastructure development & 8 & 20 \\
\hline Involve all stakeholdersin ICT tools usage & 13 & 13 \\
\hline Acquire modern and updated ICT tools and Apps & 60 & 22 \\
\hline Total & & 100 \\
\hline
\end{tabular}

\section{Conclusion}

From the results and discussion above it was concluded that for Kigali hub to increase on accessibility and consumption of its tourism and hotel products and services, RDB as the main government marketing arm and Marriott hotel Kigali branch as one of the 5 star hotels in Kigali hub had put in place some of the ICT tools and Apps to enable accessibility and consumption. However it was concluded that the two organizations were faced with some hindering factors such as change in market trends and pandemics for example COVID 19 that had limited easy accessibility and consumption of the products and services offered in Kigali hub. On the other hand from the results it was concluded that as much as there were a number of hindering factors, suggested measures were forwarded. These included the use of modern and updated ICT tools 
International Journal of Social Science and Economic Research

ISSN: 2455-8834

Volume:06, Issue:04 "April 2021"

and Apps as well as development of ICT infrastructure to improve the accessibility and consumption of the tourism products and hotel services in Kigali hub.

\section{Recommendations}

$>$ It was recommended that RDB should invest in a variety of ICT tools and Apps that can allow easy access to the different tourism and hotel products and services in Kigali hub both locally and internationally.

$>$ It was also recommended to Marriott Hotels Kigali branch to put in place ICT tools and Apps that are easily accessible and user friendly on most of the electronic gadgets to increase accessibility and consumption of the hotel products and services locally and internationally

$>$ To the travelers/guests it was recommended that they should start to embrace the usage of different Apps and ICT tools in order to be able to access and consume the tourism and hotel products in Kigali hub.

\section{References}

Ali, A, and Frew, AJ (2014) ICT and sustainable Tourism Development: An innovative Perspective. Journal of Hospitality and Tourism Technology 5:2-16 doi: 10.1108/jHTT-12-20120034

Bzjak,B., Knezevic, M. and Cvetreznik, S. (2011), Attitude change towards guests with disabilities; ' 'reflections from tourism students', Annals of Tourism Research, Vol. 38 No. 3, pp 842-57.

Buhalis, D. (1999) Information Technology for small and Medium-sized tourism enterprises: Adaptation and benefits. Information Technology and Tourism; 21 (1): 79-95

Buhalis, D (200) Marketing the competitive destination of the future. Tourism management; 21: 97-116.

Buhalis, D. O'Connor, P. (2005). Information Communication Technology revolutionizing tourism. Tourism Recreation research. 30 (3): 716.

Buhalis, D.(2003) eTourism: Information Technology for Strategic Tourism Management. Financial Times/ prentice Hall, New York.

Buhalis, D. and Michopoulous, E. (2011) Information enabled tourism destination marketing; addressing the accessibility market. Current Issues in Tourism 14, 145-168.

Buhalis, D., and Spada, A. (2000) Destination Management Systems: Criteria for success. Information Technology and Tourism 3, 41-58. 
International Journal of Social Science and Economic Research

ISSN: 2455-8834

Volume:06, Issue:04 "April 2021"

Buhalis, D., and Zoge, M. (2007) The strategic impact of the internet on Tourism industry. In Sigala, M., Mich,L. and Murphy, J . (eds) Information and Communication Technology in Tourism 2007. ENTER: Proceedings of the international Conference in Ljubljana, Slovenia, 2007. Springer Computer Science, Springer, Wien New York, Austria, pp 481-492.

Buhalis, D., Michopoulus, E., Eichhorn, V., and Miller, G. (2005) Accessibility Market and Stakeholder Analysis-One-Stop-Shop for Accessible Tourism in Europe (OSSATE), University of Surrey, Surrey.

Cardoso, J., and Lange, C. (2007) A framework for assessing strategies and technologies for dynamic packaging applications in e Tourism. Infromation Technology and Tourism 9, 27-44.

Chen, C. (2006) Identify significant factors influencing consumer trust in an online travel site. Information Technology and Tourism 8, 197-214.

Darcy, S. (1998), Anxiety to Access: Tourism patterns and Experience of New South wales people with a Physical Disability, Tourism New South Wales, Sydney.

Darcy, S, and Dickson, T. (2009), 'A whole-of-life approach to tourism: the case for accessible tourism experiences' Journal of Hospitality and Tourism Management, Vol.16 No 1, pp. 32-44.

Han, J.H., and Mills, J.(2007)are travel websites meeting the needs of the visually impaired? Information Technology and Tourism 9, 99-113.

Han, J. H., and Mills, J. (2006) The mutual designing of travel websites; perceptions of the visually impaired. In Sigala, M, and Murphy J. (eds) Information and Communications Technology in Tourism 2006.

ENTER: Proceedings of the international Conference in Ljubljana, Slovenia, 2007. Springer Computer Science, Springer, Wien New York, Austria, pp 47-157.

Hashim, N. H., Murphy, J. and Law, R (2007) A review of hospitality website design frameworks. In Sigala, M., Mich, L. and Murphy, J (eds) Information and communications Technologies in Tourism 2007.

Israel, A.A., (2002) "A preliminary Investigation of the Importance of Site Accessibility Factors for Disables Tourists" Journal of Travel Research, 41 (1), pp. 101-104.

Kleinman, A., (2012), Sustainable Tourism Cooperative Center: understanding an evolving aspect of Australian Tourism. Sydney, Australia.

Kotler, P., Bowen, J., and Makens, J. (1999) Marketing for Hospitality and Tourism, $2^{\text {nd }}$ edn. Prentice Hall, upper Saddle River, New Jersey 
International Journal of Social Science and Economic Research

ISSN: 2455-8834

Volume:06, Issue:04 "April 2021"

Mills, J. E., Ismail, J. A., Werner, W. B., and Hackshaw, K. (2002) Cyber crimes and the travel and tourism consumer. In; Wober, K.W., Frew, A.J and Hitz, M. (eds)

Mills, J.E., Ismail, J.A., Werner, W.B. and Hackshaw, K. (2002) Cyber crimes and the travel and tourism consumer. In: Wöber, K.W., Frew, A.J. and Hitz, M. (eds) Information and Communication Technology in Tourism 2007. ENTER: Proceedings of the international Conference in Ljubljana, Slovenia, 2007. Springer Computer Science, SpringerWien New York, Austria, pp. 197-206.

Morrison, A.M., Jing, S., O'Leary, J.T. and Lipping, A.C. (2001) Predicting usage of the Internet for travel bookings: an exploratory study. Information Technology and Tourism 4, 15-30.

Morrison, A.M., Taylor, J.S., Morrison A.J. and Morrison, A.D. (1999) Marketing small hotels on the World Wide Web. Information Technology and Tourism 2, 97-113.

O’Connor, P. (1999) Electronic Information Distribution in Tourism and Hospitality. CAB International,

O'Connor, P. (2003) Room rates on the Internet - is the Web really cheaper? Journal of Service Research 1(1), 57-72.

O'Connor, P. and Frew, A. (2001) Expert perceptions on the future on hotel electronic distribution channels. In: Sheldon, P.J., Wöber, K.W. and Fesenmaier, D.R. (eds) Information and Communication Technologies in Tourism 2001. ENTER: Proceedings of the International Conference in Montreal, Canada, 2001. Springer Computer Science, Springer, Wien New York, Austria, pp 346-357.

Small, J., Darcy, S. and Parker, T. (2012), "The embodied touris experience of people with impairement: management implications beyond the visual gaze",Tourism Management, Vol. 333 No. 4 pp $941-50$

Slatin, J. and Rush, S (2003) Maximum accessibility. New York: Addison- Wesley .

Unwin, T. (2009) ICT 4D., Information and Communications Technologies for Development. Cambridge, Cambridge press. Wallingford, UK.

United Nations World Tourism Organization (2013), 'Recommendations on accessible tourism', available at http//ethics, unwto.org/content/resolutions and recommendations-tourismaccessibilty (accessed on 2/6/2020)

Yau, K.M., McKercher, B. and Parker, T.L. (2004), "Travelling with disability, more than an access issue" Annals of Tourism Research, Vol. 31 No. 4, PP 946-60. 
International Journal of Social Science and Economic Research

ISSN: 2455-8834

Volume:06, Issue:04 "April 2021"

Zins, A.H (2007), Exploring travel Information search behavior beyond common frontiers. Information Communications and Technology in Tourism 5. 233-243. 